\title{
HARMONISASI PENYELESAIAN SENGKETA MEREK DI PENGADILAN TATA USAHA NEGARA DAN PENGADILAN NIAGA
}

\author{
(Harmonization of Trademark Dispute Settlement in the Administrative Court \\ and the Commercial Court)
}

\author{
Sudarsono \\ Direktorat Jenderal Badilmiltun Mahkamah Agung Republik Indonesia \\ Jalan A Yani Kav. 58, Cempaka Putih, Jakarta Pusat, Indonesia \\ Email: darsono92@gmail.com
}

Naskah diterima: 19 Februari 2018; revisi: 5 April 2018; disetujui: 17 April 2018

\begin{abstract}
Abstrak
Dengan berlakunya Undang-Undang Nomor 20 Tahun 2016 tentang Merek dan Indikasi Geografis, maka penyelesaian sengketa Merek dilaksanakan oleh dua lembaga peradilan, yaitu Pengadilan Tata Usaha Negara dan Pengadilan Niaga. Pengadilan Tata Usaha Negara berwenang menyelesaikan sengketa penghapusan Merek terdaftar atas prakarsa Menteri, sedangkan Pengadilan Niaga berwenang menyelesaikan sengketa Pendaftaran Merek, sengketa Penghapusan Merek oleh Pihak Ketiga, Sengketa Pembatalan Merek, dan sengketa Pelanggaran Merek. Sengketa Pendaftaran Merek pada hakikatnya adalah sengketa atas Keputusan Menteri, sehingga apabila garis batas kompetensinya tidak dipertegas dapat menimbulkan tumpang tindih penyelesaian di antara kedua badan peradilan tersebut. Untuk itu dilakukanlah penelitian hukum ini, dengan menggunakan pendekatan peraturan perundang-undangan dan pendekatan konseptual. Hasilnya adalah perlu diterbitkan Surat Edaran Mahkamah Agung tentang penentuan garis batas kewenangan antara kedua lembaga peradilan tersebut, yaitu bahwa kompetensi Pengadilan Niaga adalah semua sengketa yang telah ditentukan UU Nomor 20 Tahun 2016 untuk diselesaikan oleh Pengadilan Niaga dan sengketa keperdataan yang terkait dengan Merek, sedangkan kompetensi Pengadilan Tata Usaha Negara adalah sengketa Penghapusan Merek atas prakarsa Menteri dan semua Keputusan dan/atau Tindakan Menteri yang berkaitan dengan Merek yang tidak ditentukan UU Nomor 20 Tahun 2016 untuk diselesaikan Pengadilan Niaga.
\end{abstract}

Kata Kunci: harmonisasi, kompetensi, sengketa merek

\begin{abstract}
With the enactment of Law Number 20 of 2016, the settlement of Trademark dispute is carried out by two judicial institutions: the Administrative Court and the Commercial Court. The Administrative Court is authorized to resolve the dispute of a Trademark deletion by the initiative of the Minister, while the Commercial Court is authorized to resolve the disputes of Trademark registry, Trademark deletion by Third Party, Trademark annulment, and the dispute over Trademark. The Trademark Registration Dispute is essentially a dispute over the Ministerial Decree, so if the boundary line of its authority is not confirmed it may lead to overlapping settlement between the two courts. For that purpose, this legal research is conducted using the statute approach and conceptual approach. The result is the need to be published a Supreme Court Circular Letter on the determination of the boundary of authority between the two courts, namely that the competence of the Commercial Court is all disputes that have been determined in Law Number 20 of 2016 to be resolved by the Commercial Court and civil disputes related to the Trademarks, while the competence of the Administrative Court is the dispute of a Trademark deletion by the initiative of the Minister and all decisions and/or actions of Minister relating to Trademarks that are not stipulated by Law Number 20 of 2016 to be resolved by the Commercial Court.
\end{abstract}

Keywords: harmonization, competence, trademark dispute 


\section{A. Pendahuluan}

Kemajuan teknologi informasi dan komunikasi (termasuk transportasi) telah membuat sektor perdagangan meningkat pesat dan menjadi sektor utama penggerak perekonomian suatu negara. Perdagangan di era global ini telah menjadi sektor utama dalam peningkatan kemakmuran suatu negara, sebagaimana terlihat dari $57 \%$ produk domestik kotor (GDP) Belanda dan 53\% GDP Afrika Selatan yang tergantung pada perdagangan global. ${ }^{1}$ Pemerintahan Negara Indonesia yang diamanatkan untuk "melindungi segenap bangsa Indonesia dan seluruh tumpah darah Indonesia, memajukan kesejahteraan umum, mencerdaskan kehidupan bangsa, dan ikut melaksanakan ketertiban dunia yang berdasarkan kemerdekaan, perdamaian abadi dan keadilan sosial" harus terlibat aktif dalam melindungi dan mensejahterakan warganya dalam dunia perdagangan tersebut. ${ }^{2}$ Negara tidak boleh membiarkan dunia perdagangan berjalan sendiri dengan alasan perdagangan adalah sektor privat yang sebaiknya dijauhi oleh birokrasi sebagaimana ajaran negara hukum klasik (liberale rechtsstaat), namun negara harus turut berperan menjaga keadilan dan kepastian hukum di dunia perdagangan tersebut.

Salah satu instrumen penting dalam perdagangan adalah Merek, yaitu "tanda yang dapat ditampilkan secara grafis berupa gambar, logo, nama, kata, huruf, angka, susunan warna, dalam bentuk 2 (dua) dimensi dan/atau 3 (tiga) dimensi, suara, hologram, atau kombinasi dari 2 (dua) atau lebih unsur tersebut untuk membedakan barang dan/atau jasa yang diproduksi oleh orang atau badan hukum dalam kegiatan perdagangan barang dan/atau jasa". ${ }^{3}$ Dengan adanya Merek, maka semua pihak yang terlibat dalam perdagangan (Pembeli, Penjual maupun Masyarakat) akan dipacu untuk berbuat jujur, menjaga kualitas dan inovatif. Indonesia terlibat aktif dalam upaya mewujudkan perdagangan yang adil dan berkepastian hukum melalui Merek tersebut, di antaranya dengan meratifikasi Paris Convention for the Protection of Industrial Property (Konvensi Paris) yang telah disahkan dengan Keputusan Presiden Nomor 15 Tahun 1997 dan Trademark Law Treaty (Traktat Hukum Merek) yang disahkan dengan Keputusan Presiden Nomor 17 Tahun 1997. ${ }^{4}$

Dalam upaya mewujudkan pengaturan yang lebih baik atas Merek, pada tanggal 25 Nopember 2016 telah diundangkan UndangUndang (UU) Nomor 20 Tahun 2016 tentang Merek dan Indikasi Geografis (selanjutnya disebut juga dengan UU Merek) yang merupakan pengganti dari UU Nomor 15 Tahun 2001 tentang Merek. Salah satu materi yang diatur dalam UU Merek adalah mengenai penyelesaian sengketa Merek. Jika sebelumnya berdasarkan UU Nomor 15 Tahun 2001 telah ditentukan bahwa penyelesaian sengketa Merek hanya melalui Pengadilan Niaga, maka UU Merek telah menentukan bahwa penyelesaian sengketa Merek dilaksanakan oleh dua badan peradilan, yaitu Pengadilan Niaga dan Pengadilan Tata Usaha Negara (TUN). ${ }^{5}$

Peter van den Bossche, dkk, Pengantar Hukum WTO (Jakarta: Yayasan Obor Indonesia, 2010), hlm. 1.

Alinea IV Pembukaan Undang-Undang Dasar Negara Republik Indonesia Tahun 1945.

Pasal 1 angka 1 Undang-Undang Nomor 20 Tahun 2016 tentang Merek dan Indikasi Geografis.

Penjelasan Umum Undang-Undang Nomor 20 Tahun 2016 tentang Merek dan Indikasi Geografis.

Pasal 73 Undang-Undang Nomor 20 Tahun 2016 tentang Merek dan Indikasi Geografis. 
Sebagai bentuk penguatan perlindungan hukum bagi masyarakat, pemberlakuan dual jurisdiction oleh Pengadilan Niaga dan Pengadilan Tata Usaha Negara (TUN) dalam sengketa Merek tersebut sangat bagus, namun juga memiliki sisi negatif berupa kurangnya kepastian hukum akibat adanya wilayah abu-abu (grey area) di antara kedua pengadilan tersebut. Terlebih lagi, mengingat prinsip yang dianut UU Merek adalah first to file principle bukan first come first out, di mana setiap pemegang merek yang baru akan diakui kepemilikannya atas merek tersebut jika telah melakukan pendaftaran atas merek yang dimilikinya tersebut, sehingga pada dasarnya yang menjadi pokok sengketa dalam sengketa merek adalah Keputusan Menteri atas Pendaftaran Merek. ${ }^{6}$ Keputusan Menteri atas Pendaftaran Merek dapat dikategorikan sebagai Keputusan Tata Usaha Negara sebagaimana dimaksud dalam Pasal 1 angka 9 UndangUndang Nomor 5 Tahun 1986 tentang Peradilan Tata Usaha Negara sebagaimana telah diubah dua kali terakhir dengan Undang-Undang Nomor 51 Tahun 2009 tentang Perubahan Kedua atas Undang-Undang Nomor 5 Tahun 1986 tentang Peradilan Tata Usaha Negara (selanjutnya disebut juga dengan UU Peradilan TUN) juncto Pasal 87 Undang-Undang Nomor 30 Tahun 2014 tentang Administrasi Pemerintahan (selanjutnya disebut juga UU Administrasi Pemerintahan). Sebagai Keputusan TUN, semua Keputusan Menteri atas Pendaftaran Merek pada dasarnya adalah kompetensi Pengadilan TUN. Meski demikian, UU Merek menentukan bahwa hanya Keputusan Menteri tentang Penghapusan Merek Terdaftar yang menjadi kompetensi Pengadilan TUN, sedangkan
Keputusan Menteri lainnya berupa Keputusan Menteri tentang Penolakan Pendaftaran Merek, Keputusan Menteri tentang Penghapusan Merek Atas Permohonan Pihak Ketiga, maupun Keputusan Menteri tentang Pembatalan Merek merupakan kompetensi Pengadilan Niaga. Selain beberapa Keputusan Menteri yang secara tegas telah ditentukan kompetensi badan peradilan yang harus mengadilinya, ternyata dimungkinkan juga terdapat sengketa atas Keputusan Menteri di luar yang telah ditentukan dalam UU Merek, seperti pengajuan gugatan fiktif positif sebagaimana dimaksud Pasal 53 UU Administrasi Pemerintahan juncto Peraturan Mahkamah Agung Nomor 8 Tahun 2017 tentang Pedoman Beracara untuk Memperoleh Putusan atas Penerimaan Permohonan Guna Mendapatkan Keputusan dan/atau Tindakan Badan atau Pejabat Pemerintahan.

Berangkat dari paparan di atas, perlu dilakukan penelitian hukum guna memperjelas garis batas kompetensi Pengadilan TUN dan Pengadilan Niaga dalam sengketa Merek, serta mengharmonisasikan penyelesaian sengketa Merek di antara kedua Pengadilan tersebut. Dengan adanya harmonisasi penyelesaian sengketa Merek, maka akan terwujud perlindungan dan kepastian hukum bagi masyarakat, khususnya dalam dunia perekonomian, yang pada ujungnya akan turut mempercepat laju perkembangan ekonomi nasional.

Berdasarkan hal di atas, maka yang menjadi isu hukum utama dalam tulisan ini adalah "harmonisasi penyelesaian sengketa Merek di Pengadilan TUN dan Pengadilan Niaga", yang akan meneliti: bagaimana rezim pendaftaran

\footnotetext{
6 Pasal 3 juncto Pasal 21 ayat (1) huruf a Undang-Undang Nomor 20 Tahun 2016 tentang Merek dan Indikasi
} Geografis. 
merekdalamUUMerek?; bagaimana kompetensi Peradilan TUN dan Pengadilan Niaga dalam menyelesaiakan sengketa merek menurut UU Merek?; dan bagaimana mengharmonisasikan penyelesaian sengketa merek di Pengadilan TUN dan Pengadilan Niaga?

\section{B. Metode Penelitian}

Tulisan yang berjudul "Harmonisasi Penyelesaian Sengketa Merek di Pengadilan TUN dan Pengadilan Niaga" ini didasarkan pada penelitian hukum normatif, suatu jenis penelitian yang lazim dilakukan dalam kegiatan pengembanan IImu Hukum. ${ }^{7}$ Pendekatan masalah yang digunakan untuk menjawab isu hukum dalam penelitian ini adalah menggunakan pendekatan peraturan perundang-undangan (statute approach) dan pendekatan konseptual (conceptual approach). Pendekatan peraturan perundangundangan (statute approach) dimaksudkan untuk menginventarisasi, memaparkan, menginterpretasi, mensistematisasi, dan mengevaluasi Peraturan Perundang-undangan yang ada relevansinya dengan isu hukum penelitian ini, seperti UU Nomor 48 Tahun 2009 tentang Kekuasaan Kehakiman, UU Nomor 15 Tahun 2001 tentang Merek, UU Nomor 30 Tahun 2014 tentang Administrasi Pemerintahan, UU Nomor 20 Tahun 2016 tentang Merek dan Indikasi Geografis, Peraturan Menteri Hukum dan Hak Asasi Manusia Nomor 67 Tahun 2016 tentang Pendaftaran Merek, dan seterusnya. Pendekatan konseptual (conceptual approach) dilakukan dengan mengkaji, mengidentifikasi, dan menganalisis konsep-konsep hukum yang ada relevansinya dengan pembahasan dalam penelitian ini, di antaranya konsep pendaftaran merek, konsep keputusan TUN, konsep sengketa keperdataan, dan konsep penyelesaian sengketa.

\section{Pembahasan}

\section{Rezim Pendaftaran Merek dalam UU Merek}

\section{a. Karakteristik Norma Pendaftaran Merek}

"Hak atas Merek diperoleh setelah Merek tersebut terdaftar", demikian bunyi Pasal 3 UU Merek. Ketentuan tersebut menempatkan Pendaftaran Merek sebagai satu-satunya cara bagi seseorang/badan hukum perdata untuk memperoleh hak atas suatu Merek. Meski demikian, UU Merek maupun Peraturan Menteri Hukum dan Hak Asasi Manusia Nomor 67 Tahun 2016 tentang Pendaftaran Merek (selanjutnya disebut juga dengan Permenkumham Pendaftaran Merek) tidak memberikan definisi apa yang dimaksud dengan "Pendaftaran Merek" tersebut. Kedua peraturan perundangundangan tersebut hanya mendefinisikan "Permohonan" pendaftaran merek sebegai "permintaan pendaftaran Merek yang diajukan kepada Menteri". 8 Untuk mengetahui konsep Pendafaran Merek, dapat dilacak dalam UU Nomor 20 Tahun 2016 pada Bab III (Permohonan Pendaftaran Merek) dan Bab IV (Pendaftaran Merek) juncto Permenkumham Pendaftaran Merek.

Bernard Arief Sidharta, Penelitian Hukum Normatif: Analisis Penelitian Filosofikal dan Dogmatikal Dalam Sulistyowati Irianto dan Shidarta (eds), Metode Penelitian Hukum: Konstelasi Dan Refleksi, (Jakarta: Yayasan Obor Indonesia, 2009), hlm. 142.

$8 \quad$ Pasal 1 angka 8 Undang-Undang Nomor 20 Tahun 2016 tentang Merek dan Indikasi Geografis juncto Pasal 1 angka 4 Peraturan Menteri Hukum dan Hak Asasi Manusia Nomor 67 Tahun 2016 tentang Pendaftaran Merek. 
Bab III UU Merek berisi syarat dan tata cara Permohonan Merek oleh pemohon kepada Menteri, pemeriksaan kelengkapan persyaratan, hingga pengumumannya pada Berita Resmi Merek oleh Menteri. Sedangkan Bab IV UU Merek berisi Hukum Materiil dan Hukum Formil dalam Pendaftaran Merek. Hukum Materiil Merek adalah sebagaimana Pasal 20-21 UU Merek, yang menentukan mana Merek yang boleh didaftar dan mana Merek yang harus ditolak pendaftarannya oleh Menteri. Selebihnya adalah Hukum Formil berupa prosedur bagi Menteri dalam proses Pendaftaran Merek, mulai dari pemeriksaan atas permohonan, pendaftaran merek, penerbitan Sertipikat Merek dan pengumumannya, hingga pengajuan Banding ke Komisi Banding. Dari rangkaian ketentuan tersebut, Pendaftaran Merek dapat didefinisikan sebagai kewenangan Menteri untuk mendaftarkan suatu merek yang dimohonkan oleh pemohon sesuai dengan peraturan perundang-undangan yang berlaku.

Dari definisi tersebut, dapat disimpulkan beberapa karakteristik Pendaftaran Merek, sebagai berikut:

Pertama, Pendaftaran Merek termasuk dalam rezim Hukum Publik.

Hukum dapat dibedakan dari segi kepentingan yang diaturnya, yaitu Hukum Publik dan Hukum Privat. Hukum Publik berkaitan dengan fungsi negara, sedangkan hukum privat berkaitan dengan kepentingan individu. Hukum Publik berkaitan dengan peningkatan kesejahteraan sosial dan pemberdayaan warga negara dalam lingkup kepentingan umum, yang diwujudkan dengan penerbitan aturan- aturan hukum. Sedangkan Hukum Privat adalah hubungan hukum di antara sesama warga negara, yang kepentingannya bermakna khusus (privat, perdata) di antara warga negara saja. ${ }^{9}$

Dalam konteks sengketa Merek sebagaimana diatur dalam UU Merek, terdapat empat jenis sengketa Merek, yaitu sengketa Pendaftaran Merek, sengketa Penghapusan Merek, Sengketa Pembatalan Merek, dan sengketa Pelanggaran Merek. ${ }^{10}$ Dari keempat jenis sengketa tersebut, tiga yang pertama adalah termasuk Hukum Publik, karena yang dipermasalahkan adalah Pendaftaran Merek oleh Menteri, dimana Menteri dalam melaksanakan Pendaftaran Merek tersebut adalah Pejabat Pemerintahan yang telah ditentukan kewenangan dan prosedurnya dalam penerbitan Merek berdasarkan peraturan perundang-undangan yang berlaku. Sedangkan sengketa keempat berupa sengketa Pelanggaran Merek yang diajukan oleh Pemilik Merek kepada pihak lain yang menggunakan Mereknya adalah termasuk sengketa keperdataan berupa gugatan ganti rugi, sehingga termasuk dalam Hukum Privat.

Kedua, Keputusan Pendaftaran Merek termasuk Keputusan TUN.

Definisi Keputusan TUN dapat ditemukan dalam UU Peradilan TUN, yaitu suatu penetapan tertulis yang dikeluarkan oleh badan atau pejabat TUN yang berisi tindakan hukum TUN yang berdasarkan peraturan perundang-undanganan yang berlaku, yang bersifat kongkret, individual dan final, yang menimbulkan akibat hukum bagi orang atau badan hukum perdata. ${ }^{11}$ Dengan berlakunya UU Administrasi Pemerintahan, maka pengertian Keputusan TUN tersebut di atas

\footnotetext{
Peter Machmud Marzuki, Pengantar Ilmu Hukum, (Jakarta: Prenada Media Group, 2008), hlm. 211-212.

10 Bab IV, Bab XII dan Bab XV UU Nomor 20 Tahun 2016 tentang Merek dan Indikasi Geografis.

11 Pasal 1 angka 9 UU Peradilan TUN.
} 
harus dimaknai sebagaimana ketentuan Pasal 87 Undang Undang Administrasi Pemerintahan, selengkapnya sebagai berikut:

"Dengan berlakunya UU ini, Keputusan TUN sebagaimana dimaksud dalam UU Nomor 5 Tahun 1986 tentang Peradilan TUN sebagaimana telah diubah dengan UU Nomor 9 Tahun 2004 dan UU Nomor 51 Tahun 2009 harus dimaknai sebagai:

a. penetapan tertulis yang juga mencakup tindakan faktual;

b. Keputusan Badan dan/atau Pejabat TUN di lingkungan eksekutif, legislatif, yudikatif, dan penyelenggara negara lainnya;

c. berdasarkan ketentuan perundangundanganan dan asas-asas umum pemerintahan yang baik;

d. bersifat final dalam arti lebih luas;

e. Keputusan yang berpotensi menimbulkan akibat hukum; dan/atau

f. Keputusan yang berlaku bagi Warga Masyarakat."

Dari unsur-unsur yang harus terpenuhi secara kumulatif untuk dapat disebut sebagai Keputusan TUN tersebut, apabila dihubungkan dengan Pendaftaran Merek dapat diperoleh kesimpulan sebagai berikut:

- unsur Penetapan Tertulis yang juga mencakup tindakan faktual, terlihat dari bentuk Pendaftaran Merek adalah tertulis;

- unsur dikeluarkan oleh Badan atau Pejabat TUN di lingkungan eksekutif, legislatif, yudikatif, dan penyelenggara negara lainnya, terlihat dari keputusan Pendaftaran Merek diterbitkan oleh Pejabat TUN yaitu Menteri Hukum dan Hak Asasi Manusia;

- unsur berisi Tindakan Hukum TUN, yakni tindakan Menteri dalam menerbitkan keputusan yang berkaitan dengan
Pendaftaran Merek merupakan tindakan hukum yang berada pada wilayah Hukum Administrasi Negara;

- unsur berdasarkan peraturan perundangundanganan yang berlaku dan asas-asas umum pemerintahan yang baik, terlihat penerbitan keputusan Pendaftaran Merek didasarkan pada UU Nomor 20 Tahun 2016 dan peraturan perundang-undanganan lainnya yang berkaitan;

- unsur Kongkret terlihat dari hal yang diputuskan dalam keputusan Pendaftaran Merek adalah telah nyata/berwujud dan tidak abstrak, berupa penetapan adanya hak bagi para pemegang Sertifikat Merek atas suatu merek yang memungkinkannya melakukan tindakan hukum seperti melakukan perdagangan, dan sebagainya;

- unsur Final dalam arti luas, terlihat dari keputusan Pendaftaran Merek telah bersifat definitif, sehingga telah berakibat hukum bagi Pemohon Pendaftaran Merek maupun pihak lain yang berkepentingan;

- unsur keputusan yang berlaku bagi warga masyarakat, terlihat bahwa keputusan Pendaftaran Merek ditujukan kepada Pemohon Pendaftaran Merek, dan mengikat pula pihak lain yang tidak berhak untuk tidak menggunakan merek yang telah diberikan kepada Pemohon Pendaftaran Merek.

Dengan demikian, Keputusan Menteri tentang Pendaftaran Merek telah memenuhi kriteria Keputusan TUN.

\section{b. Beberapa Prosedur Yang Berkaitan Dengan Pendaftaran Merek}

Beberapa prosedur yang berkaitan dengan pendaftaran merek diatur dalam UU Merek dan Permenkumham Pendaftaran Merek, 
terdiri dari: prosedur Pendaftaran Merek, prosedur Perpanjangan Merek, dan prosedur Penghapusan Merek.

Untuk prosedur Pendaftaran Merek pada pokoknya adalah sebagai berikut:

1) Permohonan Pendaftaran Merek.

Permohonan diajukan oleh Pemohon (orang atau badan hukum) kepada Menteri, dengan memenuhi persyaratan sebagaimana Pasal 4-10 UU Merek juncto Bab II Bagian Kesatu Permenkumham Pendaftaran Merek.

2) Pengumuman Permohonan.

Setelah berkas Permohonan lengkap, maka Menteri mengumumkan Permohonan tersebut dalam Berita Resmi Merek selama 2 (dua) bulan.

3) Keberatan dan Sanggahan.

Selama masa dua bulan Pengumuman tersebut, pihak lain yang berkepentingan dapat mengajukan Keberatan kepada Menteri atas Permohonan Pendaftaran Merek. Dan atas Keberatan tersebut, pihak Pemohon dapat mengajukan Sanggahan balik.

4) Pemeriksaan Substantif Merek.

Pemeriksaan Substantif merupakan pemeriksaan yang dilakukan oleh Pemeriksa terhadap Permohonan Pendaftaran Merek, termasuk jika ada Keberatan dan Sanggahan. Jika dalam pemeriksaan tersebut diketahui Merek yang dimohonkan memenuhi syarat, maka Menteri akan mendaftarkan Merek tersebut. Sebaliknya, jika Merek yang dimohonkan tidak memenuhi syarat, maka Menteri akan memutuskan bahwa Permohonan tidak dapat didaftar atau ditolak.

5) Tanggapan atas Penolakan Pendaftaran.

Apabila Permohonannya ditolak oleh Menteri, Pemohon dapat mengajukan
Tanggapan dalam jangka waktu 30 (tiga puluh) hari terhitung sejak ditolaknya Permohonan. Apabila Tanggapan tersebut dikabulkan, maka Menteri akan mendaftar Merek yang dimohonkan. Sebaliknya, apabila Menteri menolak Tanggapan tersebut, maka Permohonan Merek ditolak.

6) Banding.

Pemohon Pendaftaran yang ditolak oleh Menteri dapat mengajukan Banding kepada Komisi Banding Merek. Apabila permohonan Banding dikabulkan, maka Menteri akan mendaftar Merek yang dimohonkan. Sebaliknya, apabila Menteri menolak permohonan Banding tersebut, maka Permohonan Merek ditolak.

7) Gugatan ke Pengadilan Niaga.

Pemohon Pendaftaran yang Permohonan Bandingnya ditolak oleh Komisi Banding Merek, dapat mengajukan Gugatan kepada Pengadilan Niaga. Upaya Hukum atas Putusan Pengadilan Niaga adalah Kasasi ke Mahkamah Agung.

Sedangkan untuk prosedur Perpanjangan Merek pada pokoknya adalah sebagai berikut:

1) Permohonan Perpanjangan Merek diajukan oleh Pemilik Merek dalam tenggang waktu 6 (enam) bulan sebelum masa berakhirnya Merek.

2) Syarat disetujuinya Permohonan Perpanjangan Merek adalah jika Merek yang bersangkutan masih digunakan pada barang atau jasa sebagaimana dicantumkan dalam sertifikat Merek tersebut, dan barang atau jasa sebagaimana Merek tersebut masih diproduksi dan/atau diperdagangkan. Sebaliknya, jika Merek sudah tidak dipergunakan atau barangnya tidak diproduksi/diperdagangkan, maka 
Permohonan Perpanjangan Merek akan ditolak.

3) Terhadap Penolakan Permohonan Perpanjangan Merek, Pemilik Merek dapat mengajukan Permohonan Banding kepada Komisi Banding Merek. Apabila permohonan Banding dikabulkan, maka Menteri akan memperpanjang pendaftaran Merek yang dimohonkan. Sebaliknya, apabila Menteri menolak permohonan Banding tersebut, maka Permohonan Perpanjangan Merek ditolak.

4) Pemohon Perpanjangan Merek yang Permohonan Bandingnya ditolak oleh Komisi Banding Merek, dapat mengajukan Gugatan kepada Pengadilan Niaga. Upaya Hukum atas Putusan Pengadilan Niaga adalah Kasasi ke Mahkamah Agung.

Kemudian terhadap prosedur Penghapusan Merek dapat diajukan oleh Pemilik Merek, atas prakarsa Menteri, atau atas Permohonan Pihak Ketiga.

Prosedur Penghapusan Merek yang diajukan oleh Pemilik Merek:

1) Pemilik Merek mengajukan Permohonan Penghapusan Merek kepada Menteri.

2) Menteri mencatat penghapusan Merek tersebut dan mengumumkannya dalam Berita Resmi Merek.

Prosedur Penghapusan Merek atas prakarsa Menteri:

1) Menteri dapat menghapus suatu Merek apabila Merek tersebut:

a) memiliki persamaan pada pokoknya dan/ atau keseluruhannya dengan Indikasi Geografis; b) bertentangan dengan ideologi negara, peraturan perUUan, moralitas, agama, kesusilaan, dan ketertiban umum; atau

c) memiliki kesamaan pada keseluruhannya dengan ekspresi budaya tradisional, warisan budaya tak benda, atau nama atau logo yang sudah merupakan tradisi turun temurun.

2) Sebelum menyatakan penghapusannya, Menteri terlebih dahulu harus mendapatkan rekomendasi dari Komisi Banding Merek.

3) Pemilik Merek yang dihapus oleh Menteri dapat mengajukan gugatan ke Pengadilan TUN.

4) Upaya hukum atas Putusan Pengadilan TUN adalah Kasasi ke Mahkamah Agung.

Prosedur Penghapusan Merek atas Permohonan Pihak Ketiga:

1) Penghapusan Merek terdaftar dapat pula diajukan oleh pihak ketiga yang berkepentingan dalam bentuk gugatan ke Pengadilan Niaga dengan alasan Merek tersebut tidak digunakan selama 3 (tiga) tahun berturut-turut dalam perdagangan barang dan/atau jasa sejak tanggal pendaftaran atau pemakaian terakhir.

2) Apabila gugatan dikabulkan dan putusan telah berkekuatan hukum tetap, maka Penghapusan Merek terdaftar sebagaimana dimaksud pada ayat (1) dicatat dan diumumkan dalam Berita Resmi Merek.

Dari rangkaian prosedur tersebut, terbaca bahwa inti dari Pendaftaran Merek adalah Keputusan Menteri yang tergolong sebagai Keputusan TUN, karena prinsip pendaftaran yang dianut adalah first to file principle sebagaimana dimaksud Pasal 3 juncto Pasal 21 ayat (1) huruf a UU Merek. 


\section{Kompetensi Pengadilan TUN dan Pengadilan Niaga dalam penyelesaian sengketa Merek}

\section{a. Sejarah Pengaturan Kompetensi Penyelesaian Sengketa Merek}

Sebelum berlakunya UU Nomor 15 Tahun 2001, badan peradilan yang memiliki kompetensi untuk menyelesaikan sengketa Merek adalah Pengadilan Negeri dan Pengadilan TUN. Pengadilan Negeri berwenang menyelesaikan sengketa keperdataan yang berkaitan dengan Merek, sedangkan Pengadilan TUN berwenang mengadili sengketa Merek akibat dikeluarkannya Keputusan TUN yang berkaitan dengan Merek. Penjelasan UU Nomor 14 Tahun 1997 angka 12 telah menyebutkan kewenangan Pengadilan TUN dalam sengketa Merek tersebut, sebagai berikut:

"Perubahan ketentuan Pasal 56 ini dilakukan pada ayat (1), ayat (2), dan ayat (4). Penambahan alasan yang merujuk pada Pasal 4 ayat (1) untuk memperjelas maksud atau konsepsi yang terkandung dalam Pasal 56 ini, yaitu meninjau kembali kedudukan merek yang didaftar dengan maksud terselubung atau itikad tidak baik dari pendaftarnya. Adapun tujuan perubahan ayat (4), untuk menegaskan adanya hak bagi setiap orang atau badan hukum yang berkepentingan untuk mengajukan gugatan pembatalan merek. Dengan perubahan ini maka penjelasan ayat (4) sekaligus dapat diperbaiki. Artinya, penjelasan ayat (4) tersebut harus dibaca dengan pengertian bahwa gugatan pembatalan melalui Pengadilan Negeri terhadap pemilik merek dan Kantor Merek, tidak mengurangi kesempatan bagi penggugat untuk mengajukan gugatannya kepada Pengadilan TUN, sepanjang gugatan tersebut memenuhi persyaratan sebagaimana dimaksud dalam Pasal 53 ayat (2) dan Pasal 55 UU Nomor 5 Tahun 1986 tentang Peradilan TUN".
Dualisme kewenangan antara Peradilan Umum dan Peradilan TUN tersebut berakhir dengan diundangkannya UU Nomor 15 Tahun 2001, yang dalam Penjelasan Umumnya menyatakan bahwa Merek merupakan bagian dari kegiatan perekonomian/dunia usaha, sehingga penyelesaian sengketa Merek memerlukan badan peradilan khusus, yaitu Pengadilan Niaga yang diharapkan dapat menyelesaikan sengketa Merek dalam waktu yang relatif cepat. Dengan berlakunya UU Nomor 15 Tahun 2001, maka semua sengketa yang berkaitan dengen Merek diselesaikan oleh pengadilan khusus di lingkungan Peradilan Umum berupa Pengadilan Niaga. Dengan demikian, Peradilan TUN tidak lagi memiliki kewenangan mengadili sengketa Merek.

Semenjak diberlakukannya UU Merek pada tanggal 25 Nopember 2016, dualisme kewenangan dalam penyelesaian sengketa Merek kembali terjadi, bukan lagi antara Pengadilan Negeri dengan Pengadilan TUN sebagaimana saat berlakunya UU Nomor 14 Tahun 1997, namun antara Pengadilan Niaga dan Pengadilan TUN. Berdasarkan Pasal 72 ayat (6) UU Merek, Pengadilan TUN berwenang mengadili Penghapusan Merek Terdaftar yang dilakukan atas prakarsa Menteri. Adapun kebanyakan sengketa lainnya diadili oleh Pengadilan Niaga. Dilihat dari segi positif, adanya kewenangan Pengadilan TUN dalam sengketa Merek diharapkan dapat memberikan perlindungan hukum yang lebih baik bagi masyarakat, mengingat Pengadilan TUN adalah pengadilan yang secara khusus dimaksudkan untuk melaksanakan kontrol yuridis atas tindak pemerintahan, di mana hukum acaranya memungkinkan Hakim Pengadilan TUN secara efektif memberikan perlindungan kepada masyarakat, misalnya melalui prosedur 
Pemeriksaan Persiapan ataupun prosedur Penundaan (schorsing) keberlakuan suatu Keputusan TUN yang sedang digugat. ${ }^{12}$ Sebaliknya dari segi negatif, mengingat karakter norma Pendaftaran Merek adalah Keputusan TUN yang pada asasnya adalah kompetensi Peradilan TUN, dimungkinkan adanya wilayah abu-abu (grey area) dalam penyelesaian sengketa Merek antara Pengadilan TUN dan Pengadilan Niaga, yang harus segera diperjelas guna menghindarkan ketidak-pastian hukum.

\section{b. Kompetensi Pengadilan TUN dalam penyelesaian sengketa Merek}

Pengadilan TUN adalah salah satu badan peradilan di bawah Mahkamah Agung, yang berwenang memeriksa, mengadili, memutus, dan menyelesaikan Sengketa TUN. Sengketa TUN adalah sengketa yang timbul dalam bidang TUN antara orang atau badan hukum perdata dengan badan atau pejabat TUN, baik di pusat maupun di daerah, sebagai akibat dikeluarkannya Keputusan TUN. Keputusan TUN adalah suatu penetapan tertulis yang dikeluarkan oleh badan atau pejabat TUN yang berisi tindakan hukum TUN yang berdasarkan peraturan perundang-undanganan yang berlaku, yang bersifat konkret, individual, dan final, yang menimbulkan akibat hukum bagi seseorang atau badan hukum perdata. Dengan diundangkannya UU Administrasi Pemerintahan, maka kompetensi Pengadilan TUN ditambah menjadi lebih luas, yaitu meliputi Keputusan, ${ }^{13}$ Tindakan, ${ }^{14}$ Permohonan
Pengujian Penyalahgunaan Wewenang, ${ }^{15}$ dan Permohonan Fiktif Positif. ${ }^{16}$

Kompetensi Pengadilan TUN dalam sengketa Merek hanya terbatas pada Penghapusan Merek Terdaftar yang dilakukan atas prakarsa Menteri, sebagaimana dimaksud Pasal 72 ayat (6) UU Merek. Penghapusan Merek terdaftar dapat dilakukan atas prakarsa Menteri, apabila Merek tersebut:

a. memiliki persamaan pada pokoknya dan/ atau keseluruhannya dengan Indikasi Geografis;

b. bertentangan dengan ideologi negara, peraturan perundang-undangan, moralitas, agama, kesusilaan, dan ketertiban umum; atau

c. memiliki kesamaan pada keseluruhannya dengan ekspresi budaya tradisional, warisan budaya tak benda, atau nama atau logo yang sudah merupakan tradisi turun temurun.

Prosedur Penghapusan Merek yang disebabkan salah satu dari tiga hal di atas adalah Menteri terlebih dahulu mengajukan permintaan rekomendasi kepada Komisi Banding Merek, dan sesudah mendapatkan rekomendasi dari Komisi Banding Merek, Menteri dapat menghapus Merek tersebut. Pemilik Merek yang keberatan terhadap keputusan penghapusan Merek terdaftar atas prakarsa Menteri dapat mengajukan gugatan melalui Pengadilan TUN. Upaya hukum atas putusan Pengadilan TUN hanya kasasi ke Mahkamah Agung.

Pasal yang mengatur tentang pengajuan gugatan ke Pengadilan TUN sebagaimana UU

Pasal 63 dan Pasal 67 UU Peradilan TUN.

Pasal 1 angka 7 juncto 87 Undang-Undang Nomor 30 Tahun 2014 tentang Administrasi Pemerintahan.

Pasal 1 angka 7 juncto 87 Undang-Undang Nomor 30 Tahun 2014 tentang Administrasi Pemerintahan.

15 Pasal 21 Undang-Undang Nomor 30 Tahun 2014 tentang Administrasi Pemerintahan.

16 Pasal 53 Undang-Undang Nomor 30 Tahun 2014 tentang Administrasi Pemerintahan. 
Merek hanya satu pasal, dan apabila dikaitkan dengan proses pemeriksaan di Pengadilan TUN sebagaimana UU Peradilan TUN, perlu ditegaskan hal-hal sebagai berikut:

Pertama, Acara Pemeriksaannya. Penyelesaian sengketa Merek di Pengadilan TUN dapat dilaksanakan dengan Acara Biasa atau Acara Cepat apabila ada kepentingan penggugat yang sangat mendesak.

Kedua, Sengketa Merek Fiktif Positif. Pasal 53 UU Administrasi Pemerintahan juncto Peraturan Mahkamah Agung Nomor 8 Tahun 2017 tentang Pedoman Beracara untuk Memperoleh Putusan atas Penerimaan Permohonan Guna Mendapatkan Keputusan dan/atau Tindakan Badan atau Pejabat Pemerintahan, telah memberikan kewenangan penyelesaian sengketa Fiktif Positif di Pengadilan TUN, yaitu sengketa yang diajukan Pemohon yang dianggap dikabulkan akibat Badan/Pejabat Pemerintahan tidak menetapkan Keputusan/Tindakan yang dimohonkan. Dalam hal Pendaftaran Merek, dimungkinkan adanya sengketa Fiktif Positif ini, yaitu bilamana Menteri hingga jangka waktu yang telah ditentukan tidak/belum menetapkan Keputusannya. Sebagai contoh, berdasarkan Pasal 28 ayat (1) Permenkumham Pendaftaran Merek dinyatakan bahwa "Menteri melakukan pencatatan perpanjangan jangka waktu perlindungan Merek terdaftar dalam jangka waktu paling lama 2 (dua) bulan sejak tanggal diterimanya Permohonan dan dinyatakan lengkap", sehingga apabila Menteri tidak mendaftarkan perpanjangan Merek dalam jangka waktu 2 (dua) bulan tersebut, maka berdasarkan Pasal 53 UU Administrasi
Pemerintahan juncto Peraturan Mahkamah Agung Nomor 8 Tahun 2017, Menteri dianggap mengabulkan permohonan perpanjangan tersebut, dan Pemohon dapat mengajukan Permohonan Fiktif Positif di Pengadilan TUN. Ketentuan tentang sengketa Fiktif Positif berkaitan dengan Merek ini belum diatur dalam UU Merek, demikian juga dengan berbagai Keputusan dan/atau Tindakan Pemerintahan berkaitan dengan Merek yang mungkin diajukan di Pengadilan TUN.

Ketiga, Upaya Administratif. Upaya Administratif terdiri dari Keberatan dan Banding Administratif, yang harus ditempuh terlebih dahulu oleh orang/badan hukum sebelum mengajukan gugatan ke Pengadilan TUN. ${ }^{17}$ Dalam konteks sengketa Merek di Pengadilan TUN, berdasarkan Pasal 72 UU Merek, Menteri sebelum menerbitkan Keputusan Penghapusan Merek terlebih dahulu harus meminta rekomendasi dari Komisi Banding Merek, sebuah komisi yang berdasarkan Peraturan Pemerintah Nomor 7 Tahun 2005 tentang Susunan Organisasi, Tugas, Dan Fungsi Komisi Banding Merek adalah badan yang menjalankan fungsi Banding Administratif dalam sengketa Merek. Dengan telah adanya rekomendasi dari Komisi Banding Merek sebelum penerbitan Keputusan Penghapusan Merek oleh Menteri, maka orang/badan hukum yang dirugikan dengan adanya Keputusan TUN tentang Penghapusan Merek atas Prakarsa Menteri tidak perlu lagi mengajukan upaya Banding Administratif ke Komisi Banding Merek, namun dapat langsung mengajukan gugatannya ke Pengadilan TUN.

$17 \quad$ Pasal 74 ayat (1) dan ayat (2) UU Administrasi Pemerintahan juncto Pasal 48 ayat (2) UU Peradilan TUN. 


\section{c. Kompetensi Pengadilan Niaga dalam Penyelesaian Sengketa Merek}

Pengadilan Niaga adalah salah satu Pengadilan Khusus di lingkungan Peradilan Umum. Pengadilan Khusus adalah Pengadilan yang mempunyai kewenangan untuk memeriksa, mengadili dan memutus perkara tertentu, yang kedudukannya berada di dalam salah satu lingkungan peradilan di bawah Mahkamah Agung, yaitu di bawah lingkungan Peradilan Umum, lingkungan Peradilan Agama, lingkungan Peradilan Militer, atau lingkungan Peradilan TUN, sebagaimana Pasal 27 ayat (1) UU Nomor 48 Tahun 2009 tentang Kekuasaan Kehakiman (selanjutnya disebut juga dengan UU Kekuasaan Kehakiman) juncto Pasal 1 angka 5 UU Nomor 49 Tahun 2009 tentang Perubahan Kedua Atas Undang-Undang Nomor 2 Tahun 1986 tentang Peradilan Umum.

Pengadilan Niaga kali pertama dibentuk di Pengadilan Negeri Jakarta Pusat, berdasarkan Pasal 281 ayat (1) Peraturan Pemerintah Pengganti Undang-Undang Nomor 1 Tahun 1998 tentang Perubahan atas UndangUndang tentang Kepailitan yang selanjutnya menjadi UU Nomor 4 Tahun 1998 tentang Penetapan Peraturan Pemerintah Pengganti Undang-Undang Nomor 1 Tahun 1998 tentang Perubahan Atas Undang-Undang tentang Kepailitan Menjadi Undang-Undang. Pada awalnya, Pengadilan Niaga adalah sebagai Pengadilan Khusus yang memiliki kompetensi menyelesaikan perkara kepailitan. Selanjutnya Pengadilan Niaga berdasarkan UU Nomor 15 Tahun 2001 diberi wewenang menyelesaikan sengketa Merek, dengan harapan penyelesaian sengketa Merek dapat dilaksanakan dalam waktu yang relatif cepat. ${ }^{18}$
Berdasarkan UU Nomor 15 Tahun 2001, semua sengketa yang berkaitan dengan Merek menjadi kompetensi Pengadilan Niaga. Pada saat itu, tidak terjadi duality of jurisdiction antara Pengadilan Niaga dengan Pengadilan TUN. Dengan berlakunya UU Merek pada saat ini, maka kompetensi Pengadilan Niaga adalah dalam penyelesaian sengketa Merek meliputi:

1) Gugatan atas Penolakan Penerbitan Keputusan Pendaftaran Merek, terdapat pada Pasal 30 UU Merek yang menentukan bahwa apabila Komisi Banding Merek menolak permohonan Banding yang diajukan Pemohon Merek, maka Pemohon Merek dapat mengajukan gugatan ke Pengadilan Niaga.

2) Gugatan Penghapusan Merek terdaftar oleh Pihak Ketiga, diatur melalui Pasal 74 UU Merek menentukan bahwa Penghapusan Merek terdaftar dapat diajukan oleh pihak ketiga yang berkepentingan dalam bentuk gugatan ke Pengadilan Niaga dengan alasan Merek tersebut tidak digunakan selama 3 (tiga) tahun berturut-turut dalam perdagangan barang dan/atau jasa sejak tanggal pendaftaran atau pemakaian terakhir.

3) Gugatan Pembatalan Merek terdaftar, diatur melaluiPasal 76 UU Merek mengatur bahwa pihak ketiga yang berkepentingan dapat mengajukan gugatan Pembetalan Merek terdaftar apabila Merek tersebut melanggar ketentuan Pasal 20 dan/atau Pasal 21 UU Merek.

4) Gugatan atas Pelanggaran Merek, Pasal 83 UU Merek mengatur bahwa Pemilik Merek terdaftar dapat mengajukan gugatan ganti

18 Paragraf 7 Penjelasan Umum UU Nomor 15 Tahun 2001 tentang Merek. 
rugi kepada pihak ketiga yang menggunakan Mereknya.

Dari keempat macam gugatan Merek yang menjadi kompetensi Pengadilan Niaga tersebut, hanya gugatan atas Pelanggaran Merek oleh Pemilik Merek kepada pihak ketiga yang berada pada ranah keperdataan, sedangkan ketiga bentuk gugatan lainnya termasuk ranah publik karena hakikat yang dipermasalahkan adalah Keputusan Menteri. Selain keempat macam model sengketa di Pengadilan Niaga tersebut, sengketa keperdataan lainnya yang berkaitan dengan Merek juga harus diselesaikan oleh Pengadilan Niaga sebagai Pengadilan Khusus yang menyelesaikan sengketa keperdataan berkaitan dengan Merek sebagaimana dimaksud Pasal 25 ayat (2) juncto Pasal 27 ayat (1) UU Kekuasaan Kehakiman.

\section{Harmonisasi Penyelesaian Sengketa Merek}

Harmonisasi penyelesaian sengketa Merek berkaitan erat dengan keberlakuan (gelding) kaidah hukum. Bruggink menyampaikan adanya tiga macam keberlakuan kaidah hukum, yaitu keberlakuan faktual atau empiris, keberlakuan normatif atau formal, dan keberlakuan evaluatif. Dari ketiga macam keberlakuan tersebut, yang paling relevan dalam konteks harmonisasi penyelesaian sengketa Merek adalah keberlakuan normatif atau formal. Keberlakuan normatif atau formal suatu kaidah hukum terwujud apabila "kaidah tersebut merupakan bagian dari suatu sistem kaidah hukum tertentu yang di dalamnya kaidah-kaidah hukum itu saling menunjuk dari satu terhadap yang lain, dimana kaidah hukum khusus bertumpu pada kaidah-kaidah hukum umum, dan setiap kaidah hukum harus diderivasi dari sistem hukum itu". ${ }^{19}$ Sistem Peradilan Indonesia terdiri dari empat lingkungan peradilan, yang dalam UU Kekuasaan Kehakiman dinyatakan terdiri atas:

1) Peradilan Umum, yang berwenang memeriksa, mengadili, dan memutus perkara pidana dan perdata sesuai dengan ketentuan peraturan perundang-undanganan. ${ }^{20}$

2) Peradilan Agama, yang berwenang memeriksa, mengadili, memutus, dan menyelesaikan perkara antara orangorang yang beragama Islam sesuai dengan ketentuan peraturan perundangundanganan. ${ }^{21}$

3) Peradilan Militer, yang berwenang memeriksa, mengadili, dan memutus perkara tindak pidana militer sesuai dengan ketentuan peraturan perundangundanganan. ${ }^{22}$

4) Peradilan TUN, yang berwenang memeriksa, mengadili, memutus, dan menyelesaikan sengketa TUN sesuai dengan ketentuan peraturan perundang-undanganan. ${ }^{23}$

Dalam setiap lingkungan peradilan tersebut dapat dibentuk Pengadilan Khusus, yang merupakan diferensiasi atau spesialisasi di setiap lingkungan peradilan, antara lain adalah Pengadilan Anak, Pengadilan Niaga, Pengadilan Hak Asasi Manusia, Pengadilan Tindak Pidana Korupsi, Pengadilan Hubungan Industrial dan

\footnotetext{
J.J.H. Bruggink, Refleksi Tentang Hukum, (Bandung: Citra Aditya Bakti, 1999), hlm. 149-152.

Pasal 25 ayat (2) UU Kekuasaan Kehakiman.

Pasal 25 ayat (3) UU Kekuasaan Kehakiman.

Pasal 25 ayat (4) UU Kekuasaan Kehakiman.

Pasal 25 ayat (5) UU Kekuasaan Kehakiman.
} 
Pengadilan Perikanan yang berada di lingkungan Peradilan Umum, serta Pengadilan Pajak yang berada di lingkungan Peradilan TUN. ${ }^{24}$ Dengan demikian, Pengadilan Niaga adalah Pengadilan Khusus di lingkungan Peradilan Umum, yang kompetensinya menyelesaikan sengketa dalam rumpun keperdataan sebagaimana dimaksud Pasal 25 ayat (2) UU Kekuasaan Kehakiman.

Dari empat jenis sengketa atas Merek yang diatur dalam UU Merek, hanya satu jenis sengketa yang bersifat keperdataan, sedangkan tiga lainya pada dasarnya adalah Sengketa TUN, karena yang dipermasalahakan adalah Keputusan Menteri berkaitan dengan pendaftaran Merek. Meski demikian, UU Merek telah menentukan hanya Sengketa Penghapusan Merek atas prakarsa Menteri yang menjadi Kompetensi Pengadilan TUN, sedangkan sengketa atas Pendaftaran Merek hingga Sengketa Pembatalan Merek menjadi kewenangan Pengadilan Niaga. Pemilahan kompetensi peradilan dalam penanganan sengketa Merek ini tidak tegas dan tidak sesuai dengan konsep kompetensi tiap lingkungan peradilan sebagaimana dimaksud Pasal 25 UU Kekuasaan Kehakiman, karena baik Pendaftaran Merek, Penghapusan Merek, maupun Pembatalan Merek ditetapkan oleh Menteri dalam norma konkrit individual (beschikking) yang semestinya menjadi kompetensi Peradilan TUN. Semestinya, jika memang sengketa Merek tersebut harus diselesaikan oleh dua lingkungan peradilan, maka pemilahan kompetensinya harus disesuaikan dengan kompetensi peradilan, yaitu semua penetapan oleh Menteri yang termasuk Keputusan TUN menjadi kompetensi Peradilan TUN, sedangkan sengketa antara pemilik Merek dengan pihak lain yang bersifat keperdataan diselesaikan oleh Pengadilan Niaga sebagai Pengadilan Khusus di Lingkungan Peradilan Umum. Atau pilihan lainnya berdasarkan efisiensi ditentukan bahwa semua sengketa yang berkaitan dengan Merek diselesaikan oleh Pengadilan Niaga, sebagaimana yang telah dilaksanakan berdasarkan UU Nomor 15 Tahun 2001, sehingga pada saat tersebut (sampai dengan berlakunya UU Merek saat ini) Peradilan TUN tidak memiliki kompetensi atas sengketa Merek.

Namun mengingat UU Merek ini telah disahkan dan menjadi hukum positif yang harus dipatuhi, termasuk oleh Mahkamah Agung dan badan peradilan di bawahnya, perlu adanya kejelasan kompetensi di antara kedua badan peradilan tersebut sehingga akan terwujud kepastian dan kesatuan hukum. Jangan sampai muncul wilayah abu-abu yang dapat dimanfaatkan oleh para pihak berkepentingan, misalnya dengan mengajukan gugatan di kedua Pengadilan tersebut untuk mengartikulasikan kepentingannya. Untuk itu, perlu adanya penegasan garis batas kompetensi di antara kedua pengadilan tersebut, yang menurut Penulis berupa: kompetensi Pengadilan Niaga dalam sengketa Merek adalah semua sengketa Merek yang telah ditentukan dalam UU Merek untuk diselesaikan oleh Pengadilan Niaga ditambah dengan sengketa keperdataan yang terkait dengan Merek, sedangkan kompetensi Pengadilan TUN adalah sengketa Penghapusan Merek atas prakarsa Menteri ditambah dengan semua Keputusan dan/atau Tindakan Menteri yang berkaitan dengan Merek yang tidak diatur dalam UU Merek untuk diselesaikan oleh Pengadilan Niaga, seperti sengketa Permohonan Fiktif Positif atas Merek. Pembagian kompetensi

$24 \quad$ Penjelasan Pasal 27 ayat (1) Undang-Undang Nomor 48 Tahun 2009 tentang Kekuasaan Kehakiman. 
tersebut sesuai dengan pembahasan pada point C.2.b dan point C.2.c di atas, dan dapat digambarkan dalam bagan sebagai berikut:

\begin{tabular}{|c|c|}
\hline $\begin{array}{c}\text { Kompetensi Pengadilan } \\
\text { TUN }\end{array}$ & $\begin{array}{c}\text { Kompetensi } \\
\text { Pengadilan Niaga }\end{array}$ \\
\hline $\begin{array}{l}\text { Penghapusan Merek } \\
\text { Terdaftar yang dilakukan } \\
\text { atas prakarsa Menteri } \\
\text { sebagaimana dimaksud } \\
\text { Pasal } 73 \text { UU Merek. }\end{array}$ & $\begin{array}{l}\text { Semua sengketa } \\
\text { Merek yang telah } \\
\text { ditentukan UU Merek } \\
\text { untuk diselesaikan } \\
\text { oleh Pengadilan Niaga, } \\
\text { mulai dari sengketa } \\
\text { Pendaftaran Merek } \\
\text { hingga sengketa } \\
\text { Pelanggaran Merek. }\end{array}$ \\
\hline $\begin{array}{l}\text { Semua Keputusan dan/ } \\
\text { atau Tindakan Menteri } \\
\text { berkaitan dengan Merek } \\
\text { selain dari Keputusan } \\
\text { Menteri yang oleh UU } \\
\text { Merek telah ditetapkan } \\
\text { sebagai kompetensi } \\
\text { Pengadilan Niaga. }\end{array}$ & $\begin{array}{l}\text { Semua jenis sengketa } \\
\text { keperdataan yang } \\
\text { terkait dengan Merek. }\end{array}$ \\
\hline
\end{tabular}

Penegasan garis batas kompetensi ini juga sesuai dengan kompetensi Lingkungan Peradilan Umum yang membawahi Pengadilan Niaga dan Kompetensi Peradilan TUN sebagaimana dimaksud Pasal 25 UU Kekuasaan Kehakiman. Penegasan garis batas kompetensi ini juga dapat memberikan perlindungan hukum yang lebih baik bagi masyarakat atas berbagai tindakan Menteri yang tidak diatur secara tegas menjadi kompetensi Pengadilan TUN maupun Pengadilan Niaga.

Pemetaan dan pemilahan secara tegas garis batas kompetensi tersebut mutlak dilakukan, karena dengan adanya kejelasan kompetensi di antara kedua badan peradilan tersebut, dapat dihindari tumpang tindih kompetensi yang dapat dimanfaatkan oleh pihak-pihak yang berkepentingan. Mahkamah Agung harus segera menentukan garis batas kompetensi di antara kedua badan peradilan tersebut, yang dalam hal ini secara internal dapat diterbitkan Surat Edaran Mahkamah Agung. Pemilihan Surat Edaran Mahkamah Agung sebagai produk hukum yang dipilih untuk menentukan garis batas kompetensi antar badan peradilan tersebut mengingat Surat Edaran Mahkamah Agung merupakan "bentuk edaran pimpinan Mahkamah Agung ke seluruh jajaran peradilan yang berisi bimbingan dalam penyelenggaraan peradilan". ${ }^{25}$

Dengan adanya kejelasan kompetensi badan peradilan mana yang berwenang menyelesaikan suatu sengketa Merek, maka akan dihasilkan keadilan, kepastian hukum dan kemanfaatan bagi para pihak yang bersengketa. Tanpa adanya kejelasan kompetensi tersebut, kedua badan peradilan yang memang berwenang mengadili sengketa Merek tersebut dapat dijadikan media permainan oleh para pihak untuk mengertikulasikan kepentingannya. Dan hal ini adalah bentuk pengingkaran atas spirit asas peradilan sederhana, cepat dan biaya ringan sebagaimana dimaksud Pasal 2 ayat (4) UU Kekuasaan Kehakiman.

\section{Penutup}

Berdasarkan Pembahasan di atas, dapat disimpulkan bahwa norma Pendaftaran Merek adalahtermasukHukum Publik, yangkarakternya adalah Keputusan TUN, yang dituangkan dalam bentuk Keputusan Menteri. Beberapa prosedur berkaitan dengan pendaftaran Merek

25 Lampiran Keputusan Ketua Mahkamah Agung Nomor 57/KMA/SK/IV/2016 tentang Pedoman Penyusunan Kebijakan Mahkamah Agung Republik Indonesia. 
yang diatur dalam UU Merek adalah prosedur Pendaftaran Merek, prosedur Perpanjangan Merek, dan Prosedur Penghapusan Merek.

Sebelum berlakunya UU Nomor 15 Tahun 2001, badan peradilan yang berwenang menyelesaikan sengketa Merek adalah Pengadilan Negeri dan Pengadilan TUN. Sesudah berlakunya UU Nomor 15 Tahun 2001, semua sengketa Merek diselesaikan oleh Pengadilan Niaga. Dengan berlakunya UU Merek pada saat ini, maka yang berwenang menyelesaikan sengketa Merek adalah Pengadilan Niaga dan Pengadilan TUN. Terdapat empat jenis sengketa Merek yang menjadi kompetensi Pengadilan Niaga, yaitu sengketa akibat penolakan Pendaftaran Merek, sengketa Penghapusan Merek oleh Pihak Ketiga, Sengketa Pembatalan Merek, dan sengketa Pelanggaran Merek. Dari keempat jenis sengketa tersebut, hanya sengketa Pelanggaran Merek yang bersifat keperdataan, sedangkan tiga sengketa lainnya bersifat publik dan mempermasalahkan Keputusan Menteri atas pendaftaran Merek. Selain itu, sengketa keperdataan lainnya berkaitan dengan Merek yang belum diatur dalam UU Merek adalah kompetensi Pengadilan Niaga. Sedangkan kompetensi Pengadilan TUN dalam sengketa Merek sebagaimana diatur dalam UU Merek hanya terbatas pada Penghapusan Merek Terdaftar yang dilakukan atas prakarsa Menteri. UUMerektidakmengaturpenyelesaian sengketa Fiktif Positif atas Merek maupun perlindungan hukum akibat adanya Keputusan dan/atau Tindakan Menteri lainnya yang berkaitan dengan Pendaftaran Merek, yang semestinya juga menjadi kompetensi Pengadilan TUN.

Perlu adanya harmonisasi kompetensi Pengadilan Niaga dan Pengadilan TUN, agar tidak timbul tumpang tindih penyelesaian sengketa Merek, yaitu dengan menentukan bahwa kompetensi Pengadilan Niaga adalah semua sengketa Merek yang telah ditentukan dalam UU Merek untuk diselesaikan oleh Pengadilan Niaga dan sengketa keperdataan yang terkait dengan Merek, sedangkan kompetensi Pengadilan TUN adalah sengketa Penghapusan Merek atas prakarsa Menteri dan semua Keputusan dan/ atau Tindakan Menteri yang berkaitan dengan Merek yang tidak diatur dalam UU Merek untuk diselesaikan oleh Pengadilan Niaga, seperti sengketa Permohonan Fiktif Positif atas Merek.

Oleh sebab itu di dalam penyusunan UndangUndang yang memberikan kewenangan kepada badan peradilan tertentu untuk mengadili sengketa tertentu, harus menyesuaikan antara jenis sengketanya dengan lembaga peradilan yang akan dibabani untuk mengadilinya. Kemudian terhadap sengketa atas berbagai Keputusan dan/atau Tindakan Menteri terkait Merek yang tidak diatur dalam UU Nomor 20 Tahun 2016 harus diberikan perlindungan hukum melalui Pengadilan TUN, dan terhadap sengketa keperdataan yang tidak diatur dalam UU Nomor 20 Tahun 2016 harus diberikan perlindungan hukum melalui Pengadilan Niaga. Dan diharapkan Mahkamah Agung dapat menerbitkan Surat Edaran Mahkamah Agung (SEMA) tentang harmonisasi penyelesaian sengketa Merek di Pengadilan TUN dan Pengadilan Niaga.

\section{Daftar Pustaka}

\section{Buku}

Apeldoorn, Van, Pengantar Ilmu Hukum, (Jakarta: Pradnya Paramita, 1986)

Bruggink, Refleksi Tentang Hukum, (Bandung: Citra Aditya Bakti, 1999)

Bossche, Peter van den, dkk, Pengantar Hukum WTO, (Jakarta: Yayasan Obor Indonesia, 2010)

Hadjon(eds), Philipus, Pengantar Hukum Administrasi Indonesia, (Yogyakarta: Gadjah Mada University Press, 1991) 
H.R., Ridwan, Pengantar Hukum Administrasi Negara, (Jakarta: RajaGrafindo Persada, 2011)

Indroharto, Usaha Memahami Undang-Undang Tentang Peradilan TUN, Buku I, Beberapa Pengertian Dasar Hukum Acara TUN, (Jakarta: Pustaka Sinar Harapan, 2004)

Irianto, Sulistyowati dan Shidarta (eds), Metode Penelitian Hukum: Konstelasi Dan Refleksi, (Jakarta: Yayasan Obor Indonesia, 2009)

Marzuki, Peter Machmud, Pengantar Ilmu Hukum, (Jakarta: Prenada Media Group, 2008)

Mertokusumo, Sudikno, Hukum Acara Perdata Indonesia, (Yogyakarta: Liberty, 2006)

Pudyatmoko, Y. Sri, Perizinan: Problem dan Upaya Pembenahan, (Jakarta: Grasindo, 2009)

Soekanto, Soerjono dan Purnadi Purbacarakan, Aneka Cara Pembedaan Hukum, (Bandung: Citra Aditya Bakti, 1989)

\section{Peraturan}

Undang-Undang Dasar Negara Republik Indonesia Tahun 1945
Undang-Undang Nomor 5 Tahun 1986 sebagaimana telah diubah dua kali terakhir dengan UndangUndang Nomor 51 tentang Perubahan Kedua atas Undang-Undang Nomor 5 Tahun 1986 tentang Peradilan Tata Usaha Negara

Undang-Undang Nomor 15 Tahun 2001 tentang Merek

Undang-Undang Nomor 48 Tahun 2009 tentang Kekuasaan Kehakiman

Undang-Undang Nomor 30 Tahun 2014 tentang Administrasi Pemerintahan

Undang-Undang Nomor 20 Tahun 2016 tentang Merek dan Indikasi Geografis

Peraturan Menteri Hukum dan Hak Asasi Manusia Nomor 67 Tahun 2016 tentang Pendaftaran Merek

Keputusan Ketua Mahkamah Agung Nomor 57/ KMA/SK/IV/2016 tentang Pedoman Penyusunan Kebijakan Mahkamah Agung Republik Indonesia 